\title{
BERMAIN SAMBIL BELAJAR: PERMAINAN TRADISIONAL SEBAGAI MEDIA PENANAMAN NILAI PENDIDIKAN KARAKTER
}

\section{Arif Syamsurrijal}

Institut Agama Islam Al Hikmah Tuban

Arif_syamsurrijal@gmail.com

\begin{abstract}
The world of children is a world of play. So, using games for the learning process is the right thing to do. There are quite a number of games to choose from, but traditional games have their own uniqueness, especially Indonesia which has quite a lot of traditional games. The game is an ancestral heritage that contains many moral values. Besides being fun, this game is also a medium for internalizing noble values that should be preserved. This short article is a descriptive article that explains how the games that are now starting to be abandoned by today's children have a lot of things that we need to keep and take care of.
\end{abstract}

Keyword: Traditional Games, Indonesia, Children, Young Generation, Character Education

\begin{abstract}
Abstrak
Dunia anak adalah dunia bermain. Sehingga, penggunaan permainan untuk proses pembelajaran merupakan hal yang tepat dilakukan. Terdapat cukup banyak permainan yang dapat dipilih, namun permainan tradisional memiliki keunikan tersendiri, khususnya Indonesia yang memiliki cukup banyak permainan tradisional. Permainan tersebut merupakan warisan leluhur yang mengandung banyak nilai moral. Di samping menyenangkan, permainan ini juga merupakan media internalisasi nilai nilai luhur yang patut untuk dilestarikan. Tulisan singkat ini merupakan tulisan deskriptif yang menjelaskan bagaimana permainan yang kini mulai banyak ditinggalkan anak anak masa kini menyimpan banyak hal yang patut kita jaga dan letarikan.
\end{abstract}

Kata Kunci: Permainan Tradisional, Indonesia, Anak, Generasi Muda, Pendidikan Karakter

Program Studi Pendidikan Guru Madrasah Ibtidaiyah

STAI Al-Azhar Menganti Gresik, Indonesia

\section{Pendahuluan}

Tren tindak kriminalitas yang melibatkan anak mengalami peningkatan setiap tahunnya. Komisi Perlindungan Anak Indonesia (KPAI) menyebutkan bahwa sejak tahun 2011 sampai akhir tahun 2018, terdapat 11.116 anak yang terlibat dalam kasus criminal. Tindak criminal tersebut meliputi geng motor, begal, pencurian, kejahatan di jalan, serta pembunuhan. Komisioner KPAI Putu Elvina menyebutkan bahwa pada tahun 2011 terdapat 695 kejahatan yang melibatkan anak, sementara pada tahun 2018 meningkat menjadi 1.434 (Sindo News, 2019). Disebutkan pula bahwa anak anak yang masuk pada Lembaga Pemasyarakatan Khusus Anak (LKPA) sebanyak 23.9 persen karena kasus pencurian, 17.8 persen karena kasus narkoba, 13.2 persen karena kasus asusila dan lain sebagainya. KPAI juga menyebutkan bahwa 1.885 kasus telah ditangani selama semester pertama tahun 2018 dengan dominasi kasus berupa narkoba, pencurian, serta asusila (Detik News, 2018) 
Melihat fenomena di atas, ada hal yang urgent untuk dilakukan untuk menyelamatkan masa depan bangsa yang notabene ada di tangan anak anak dan generasi muda, yaitu dengan Pendidikan karakter. Penanaman Pendidikan karakter harus dilakukan semenjak usia dini sehingga akan tertanam dalam diri mereka. Dalam hal ini, peran orangtua dan pendidik atau guru di sekolah sangat penting karena waktu anak akan dihabiskan Bersama mereka. Penanaman pendikan karakter pada anak dapat dilakukan dengan berbagai cara atau media, termasuk di dalamnya dari bermain. Telah diketahui bahwa dunia anak adalah dunia bermain, sehingga pelajaran atau penanaman nilai pada anak dapat dilakukan dengan cara ini. Salah satu bentuk permainan yang dapat dilakukan adalah dengan mengajarkan permainan tradisional Indonesia kepada anak (Hidayati, 2020). Mengutip dari pernyataan Tashadi, permainan tradisional adalah permainan yang mengandung nilai nilai budaya tertentu serta mempunyai fungsi melatih pemainnya melakukan hal hal yang akan penting nantinya bagi kehidupan mereka di tengah masyarakat, misalnya melatih cakap berhitung, melatih kecakapan berfikir, tidak cengeng, melatih keberanian, melatih bersikap jujur dan sportif dan sebagainya (Tesalonika dan Munawar, 2016).

Indonesia yang kaya akan budaya menyimpan cukup banyak permainan tradisional, misalnya gobak sodor, petak umper, lompat tali, dakon, kotak pos, dan lain sebagainya dan setiap daerah memiliki permainan tradisionalnya sendiri-sendiri sesuai dengan kultur yang dimiliki. Namun, saat ini anak-anak dan generasi muda lebih banyak tertarik untuk bermain online games yang diakses melalui komputer atau smartphone yang dimiliki. Jika fenomena ini terus berlanjut, maka bisa jadi suatu saat permainan tradisional akan hilang sama sekali di Indonesia karena tidak ada yang melestarikan. Sehingga, menggunakan permainan tradisional sebagai media untuk menanamkan Pendidikan karakter juga secara tidak langsung mempertahankan dan menyelamatkan warisan leluhur kita.

Terdapat beberapa penelitian yang membahas tentang Pendidikan karakter sebelumnya, misalnya saja (Hidayati, 2019) dengan judul Storytelling: One Package Learning in Improving Language Skill and Implanting Character Education on Children, dimana penulis membahas tentang penggunaan bercerita (storytelling) untuk peningkatan kemampuan berbahasa dan Pendidikan karakter pada anak. Di samping itu terdapat pula tulisan dengan judul Telling About Islamic Heroes And Female Leaders: Ways of Implanting Self-Concept, Moral, And Religious Value on Children yang ditulis Hidayati (2019).

Proses pembelajaran atau internalisasi nilai moral sebaiknya memang dilakukan sejak dini, hal ini berkaitan erat dengan karakteristik anak anak yang salah satunya sangat antusias 
Ketika mempelajari sesuatu. Beberapa karakteristik yang lain disampaikan oleh Scott and Ytreberg yang menyebutkan beberapa karakteristik anak anak, yaitu:

1. They know that the world is governed by several rules. They may not always understand the rules, but they know that they are here to obey them and the rules help them to maintain a sense of security.

2. They understand a situation faster than understanding the language it uses.

3. They use language skills long before they understand the language.

4. Their own understanding comes from the hands, ears and eyes. The physical world becomes dominant.

5. They are very logical - what you say first will happen first.

6. They have very short concentration and attention time.

7. They sometimes have difficulty in knowing or understanding what is fact and what is fiction.

8. They like to play together with other people.

9. They do not always understand the world of adults.

10. They will very rarely admit that they don't know something.

11. They cannot determine what they must learn for themselves.

12. hey love to play, and will quickly learn when they feel comfortable, but they also like themselves and like to think that what they are doing is "real" work.

13. They are very enthusiastic and positive when learning something. It's important to praise them when they keep their spirits up and feel successful from the start (Hidayati, 2020)

\section{Metode Penelitian}

PAR Merupakan suatu siklus yang terus berjalan, dimana dalam prosesnya sebagai fasilitator kita harus go to the people, hidup di tengah-tengah mereka, belajar Bersama mereka juga. Jadi, peneliti atau fasilitator bukan "menggurui" namun justru malah belajar karena banyak local knowledge yang bisa jadi belum kita ketahui.

1. Langkah awal dalam melakukan PAR adalah menyiapkan diri untuk masuk (Inkluturasi), bukan sosialisasi. Kata tersebut "dihindari" dalam PAR karena halter sebut memiliki pola topdown. Pada tahap ini kita harus memahami kelompok tersebut, misalnya kelompok tani, agama, jamaah tahlil, yasinan, dan lainnya. Pada kelompok tersebut pasti memiliki tokoh dan perannya. Ada pula Lembaga sosial yang memiliki pengaruh atau yang bahkan tidak berperan. Lembaga-lembaga tersebut dapat pula kita gunakan atau kita ajak duduk Bersama 

untuk mendapatkan data. Kemudian, kita juga harus mengenali budaya, Bahasa, dan hallainnya. Pada tahap-tahap awal sebaiknya tidak menyentuh hal-hal sensitive di masyarakat. Proses ini tidak dapat diprediksi lama tidaknya. Karena indikatornya adalah Meeting of Mind.

2. Pada Langkah selanjutnya kita dapat membentuk tim yang melibatkan orang dalam (masyarakat) dan orang luar. Pada proses ini akan menggunakan alat. Pada tahap ini dilakukan social problem diagnostic atau melakukan diagnose masalah. Pada tahap ini terjadi community research, dimana ini proses mendidik kita sendiri serta mendidik masyarakat dengan tujuan memperoleh keadilan yang memihak. Riset ini nantinya harus menghasilkan pemecahan masalah dengan adanya aksi. Pada bagian bagian awal kita terjun di masyarakat, akan muncul banyak keluhan. Namun, keluhan tersebut belum tentu masalah utama, namun hanya merupakan dampak. Proses ini terjadi proses kodifikasi. Kemudian kita lakukan Analisa sosial untuk menemukan masalah utama yang sebenarnya terjadi. Pada tahap ketiga adalah Community Strategic Planning.

3. Pada tahapan ini, gagasan-gagasan yang muncul diorganisir untuk nantinya merumuskan rencana Bersama dengan masyarkat

4. Tahap keempat adalah political action

Tahap ini melakukan aksi untuk membangun kekuatan. Misalnya belum ada kelompok tani dibangun kelompok tani, tidak adak operasi dibangun koperasi, dan seterusnya. Pada proses ini terdapat beberapa hal yang dilakukan misalnya capacity building dalam pembukuan, pelatihan-pelatihan dan seterusnya. Selanjutnya dapat melakukan mobilisasi sumber daya. Selanjutnya ada monitoring dan evaluasi

5. Tahap kelima ada lagrefleksi untuk menilai apakah telah berhasil atau tidak.

\section{Diskusi}

Kata karakter dalam Kamus Besar Bahasa Indonesia (KBBI) memiliki makna tabiat, sifatsifat kejiwaan, akhlak atau budi pekerti yang membedakan seseorang dengan yang lain, dan watak. Karakter dapat pula diartikan sebagai huruf, angka, ruang, simbol khusus yang dapat dimunculkan pada layer dengan papan ketik. Mengutip dari Laman Kementerian Pendidikan dan Kebudayaan bahwa Penguatan Pendidikan Karakter (PPK) merupakan kebijakan pendidikan yang memiliki tujuan utama untuk mengimplementasikan Nawacita Presiden Joko Widodo-Jusuf Kalla dalam sistem pendidikan nasional. Kebijakan PPK ini terintegrasi dalam Gerakan Nasional Revolusi Mental (GNRM) yaitu perubahan cara berpikir, bersikap, dan bertindak menjadi lebih baik. Nilai-nilai utama PPK adalah religius, nasionalis, mandiri, gotong royong, integritas. Nilai-nilai ini ingin ditanamkan dan dipraktikkan melalui sistem pendidikan nasional agar diketahui, dipahami, dan diterapkan di seluruh sendi kehidupan di sekolah dan di masyarakat. 
PPK lahir karena kesadaran akan tantangan ke depan yang semakin kompleks dan tidak pasti, namun sekaligus melihat ada banyak harapan bagi masa depan bangsa. Hal ini menuntut lembaga pendidikan untuk mempersiapkan peserta didik secara keilmuan dan kepribadian, berupa individuindividu yang kokoh dalam nilai-nilai moral, spiritual dan keilmuan. Memahami latar belakang, urgensi, dan konsep dasar PPK menjadi sangat penting bagi kepala sekolah agar dapat menerapkannya sesuai dengan konteks pendidikan di daerah masing-masing.

Tujuan dari PPK adalah membangun dan membekali Peserta Didik sebagai generasi emas Indonesia Tahun 2045 guna menghadapi dinamika perubahan di masa depan, mengembangkan platform pendidikan nasional yang meletakkan pendidikan karakter sebagai jiwa utama dengan memperhatikan keberagaman budaya Indonesia; serta merevitalisasi dan memperkuat potensi dan kompetensi ekosistem pendidikan. Konsep dari PPK terangkum dalam diagram berikut:

\section{Gambar 1.KonsepPKK}

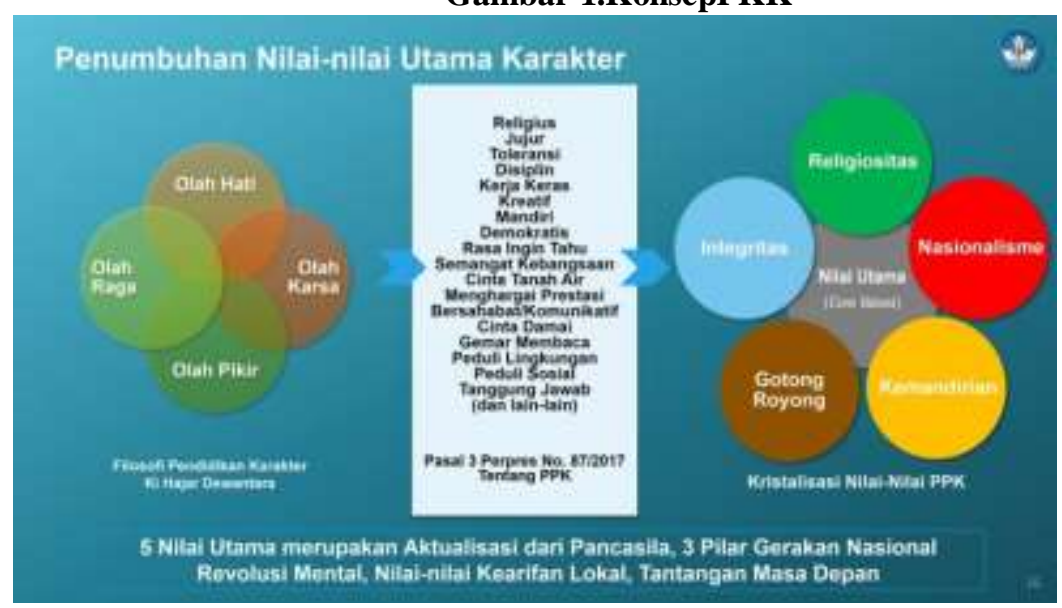

Dari gambar di atas, dapat diketahui bahwa terdapat 5 nilai utama yang digalakkan dalam usaha untuk menumbuhkan nilai-nilai karakter, yaitu religiositas, nasionalisme, kemandirian, gotong royong, serta integritas. Kelima nilai tersebut merupakan aktualisasi dari Pancasila. Sumber dari kelima nilai tersebut berdasar dari filosofi Pendidikan karakter yang disampaikan oleh Ki Hajar Dewantara berupa olah hati, olah karsa, olah piker dan olah raga.

Pada dasarnya penanaman nilai-nilai karakter yang digalakkan ini merupakan wujud usaha pemerintah untuk menyiapkan para generasi muda untuk menyongsong perkembangan yang semakin cepat. Pemerintah menyebutkan bahwa anak-anak perlu dibekali dengan 3 hal pokok, yaitu kualitas karakter, literasi dasar serta kompetensi untuk nantinya membangun generasi emas di tahun 2045 . Kualitas karakter terangkum dalam 5 core values yang telah disebutkan sebelumnya, kemudian literasi dasar mencakup literasi bahasa, numerasi, sains, digital, finansial, sera budaya dan kewargaan. Sedangkan kompetensi meliputi berfikir kritis, kreativitas, komunikasi dan kolaborasi. Hal ini terangkum dalam gambar berikut ini: 
Gambar2.MengbangunGenerasiEmas2045YangDibekaliEterampilanAbad 21

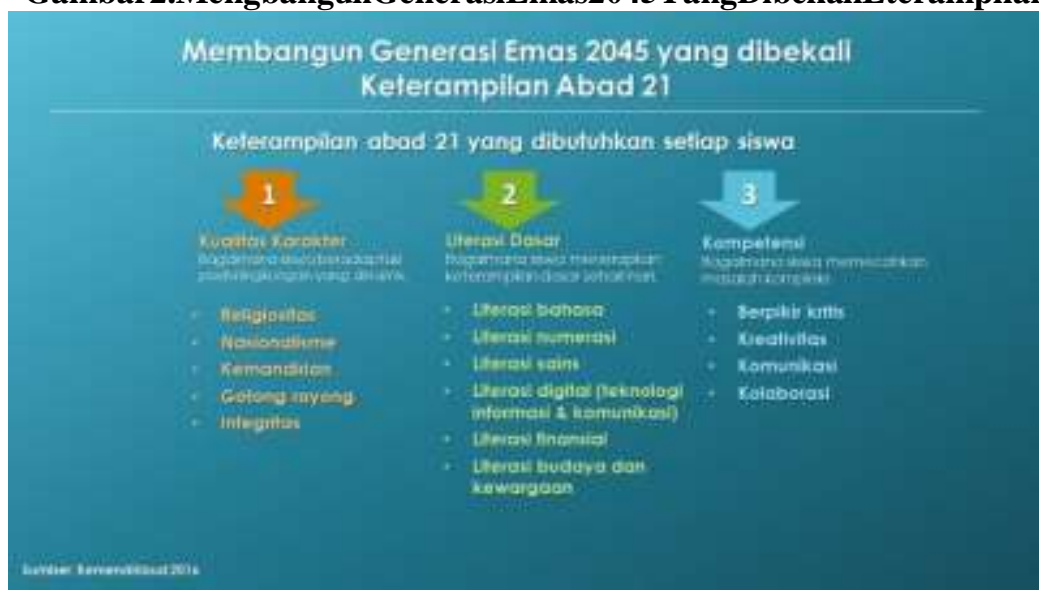

The National Association For The Education Of Young Children (NAEYC) menyebutkan bahwa early childhood adalah anak yang sejak lahir sampai dengan usia delapan tahun, pre school adalah anak antara usia 1-3 tahun dan usia masuk kelas satu biasanya antara usia 3-5 tahun, sementara toddler adalah anak yang mulai berjalan sendiri sampai dengan usia 3 tahun (Adriani, 2012). Dalam buku Pedoman Penyelenggaraan PAUD disebutkan bahwa prinsip prinsip penyelenggaraan PAUD didasarkan pada hal hal berikut ini:

1. Berorientasi pada kebutuhan anak. Kegiatan belajar harus selalu ditunjukkan pada pemenuhan kebutuhan perkembangan masing masing anak sebagai individu.

2. Kegiatan belajar dilakukan melalui bermain. Dengan bermain yang menyenangkan dapat merangsang anak untuk melakukan eksplorasi dengan menggunakan benda benda yang ada di sekitarnya, sehingga anak menemukan pengetahuan dari benda benda yang dimainkannya.

3. Merangsang munculnya kreativitas dan inovasi. Kreativitas dan inovasi tercermin melalui kegiatan yang membuat anak tertarik, focus, serius dan konsentrasi.

4. Menyediakan lingkungan yang mendukung proses belajar. Lingkungan harus diciptakan mejadi lingkungan yang menarik dan menyenangkan bagi anak selama mereka bermain.

5. Mengembangkan kecakapan hidup anak. Kecakapan hidup diarahkan untuk membantu anak menjadi mandiri, disiplin, mampu berorientasi dan memiliki ketrampilan dasar yang berguna bagi kehidupannya kelak.

6. Menggunakan berbagai sumber dan media belajar yang ada di lingkungan sekitar.

7. Dilaksanakan secara bertahap dengan mengacu pada prinsip prinsip perkembangan anak.

8. Rangsangan Pendidikan mencakup semua aspek perkembangan. Rangsangan Pendidikan bersifat menyeluruh yang mencakup semua aspek perkembangan. Saat anak melakukan sesuatu sesungguhnya ia sedang mengembangkan berbagai aspek perkembangan/kecerdasannya. 
Menurut Direktorat PAUD, prinsip perkembangan anak adalah:

1. Anak akan belajar dengan baik apabila kebutuhan fisiknya terpenuhi dan merasakan aman serta nyaman dalam lingkungannya.

2. Anak akan belajr terus menerus, dimulai dari membangun pemahaman tentang sesuatu, mengeksplorasi lingkungan, menemukan kembali suatu konsep hingga mampu membuat sesuatu yang berharga

3. Anak belajar melalui interaksi social baik dengan orang dewasa maupun teman sebaya yang ada di lingkungannya.

4. Minat dan ketekunan akan memotivasi belajar anak

5. Perkembangan dan gaya belajar anak seharusnya dipertimbangkan sebagai perbedaan individu

6. Anak belajar dari yang sederhana ke yang kompleks, dari yang konkret ke yang abstrak, dari non verbal ke yang verbal, dan dari diri sendiri ke social

Menanamkan suatu Pendidikan atau nilai sebaiknya dilakukan sejak dini, karena kita telah mengenal apa yang disebut dengan golden ages dimana otak anak menyerap sesuatu seperti spons. Di samping itu, usia dini adalah masa dimana pertumbuhan dan perkembangan mulai dan sedang berlangsung, baik itu berupa perkembangan fisiologik, bahasa, koginitif maupun motoric. (Latif, dkk., 2014) menyebutkan bahwa perkembangan di usia dini akan menentukan perkembangan anak pada tahap tahap selanjutnya. Hal serupa juga disebutkan oleh Sugito dalam tulisannya yang menyebutkan bahwa keberhasilan menjalankan tugas perkembangan dalam suatu masa akan menentukan keberhasilannya pada masa perkembangan berikutnya. Poin ini dapat dikaitkan dengan beberapa tujuan Pendidikan anak usia dini, yaitu:

1. Agar anak percaya akan adanya Tuhan dan mampu beribadah serta mencintai sesamanya

2. Agar anak mampu mengelola keterampilan tubuhnya, termasuk Gerakan motoric kasar dan motoric halus serta mampu menerima rangsangan motoric

3. Anak mampu menggunakan bahasa untuk pemahaman bahasa pasif dan dapat berkomunikasi secara efektif sehingga dapat bermanfaat untuk berpikir dan belajar

4. Anak mampu berpikir logis, kritis, memberikan alasan, memecahkan masalah dan menemukan hubungan sebab akibat

5. Anak mampu mengenal lingkungan alam, lingkungan social, peranan masyarakat, menghargai keragaman social dan budaya serta mampu mengembangkan konsep diri yang positif dan control diri.

6. Anak memiliki kepekaan terhadap irama, nada, berbagai bunyi, serta menghargai karya kreatif 
Dunia anak merupakan dunia bermain. Jean-Jacques Rousseou menyebutkan bahwa “....our first teachers are our feet, our hands, and our eyes, ....to substitute books for all these....is but to teach us to use the reasons of other...". Kita juga sering mendengar ungkapan bahwa Pendidikan anak adalah belajar sambil bermain dan bermain seraya belajar. Selamet menyebutkan bahwa permainan terbagi menjadi beberapa jenis, yaitu:

1. Permainan fisik, misalnya permainan kejar kejaran menggunakan banyak kegiatan fisik.

2. Lagu anak anak, biasanya dinyanyikan sambil bergerak, menari atau berpura pura

3. Teka teki, merupakan permainan untuk mengasah kemampuan anak untuk berfikir logis dan matematis

4. Bermain dengan benda benda, yaitu permainan dengan objek seperti air, pasir, balok yang dapat membantu anak untuk mengembangkan berbagai aspek perkembangan

5. Bermain peran, yang meliputi sandiwara, drama atau bermain peran dan jenis permainan lain dimana memainkan sebagai orang lain.

(Dharmamulya, 2008) menyebutkan bahwa terdapat tiga jenis permainan tradisional. Kategori ini didasarkan pada pola permainannya, yaitu bermain dan bernyanyi atau dialog, bermain dan olah piker, serta bermain dan adu ketangkasan. Ia juga menambahkan bahwa terdapat beberapa manfaat dari permainan ini, yaitu

1. Melatih cakap berhitung

2. Melatih kecakapan berfikir

3. Tidak cengeng, melatih keberanian

4. Melatih bersikap jujur dan sportif.

Hal yang hampir serupa disebutkan pula oleh (Misbach, 2006) yang menyebutkan bahwa terdapat beberapa aspek perkembangan anak yang dapat distimulasi oleh permainan tradisional, yaitu

a. Aspek motoric melatih daya tahan, daya lentur, sensorimotorik, motoric kasar, motoric halus

b. Aspek kognitif yang mengembangkan imajinasi, kreativitas, problem solving, strategi, antisipatif, pemahaman kontekstual

c. Aspek emosi katarsis emosional, mengasah empati, pengendalian diri

d. Aspek bahasa pemahaman konsep konsep nilai

e. Aspek sosoal menjalin relasi, kerjasama, melatih kematangan social dengan teman sebaya dan meletakkan pondasi untuk melatih ketrampilan sosialisasi berlatih peran dengan orang yang lebih dewasa atau masyarakat

f. Aspek spiritual menyadari keterhubungan dengan sesuatu yang bersifat agung

g. Aspek ekologis memahami pemanfaatan elemen elemen alam sekitar secara bijaksana

h. Aspek nilai nilai atau moral menghayati nilai nilai moral yang diwariskan dari generasi terdahulu kepada generasi selanjutnya. 
(Rogers \& Sawyer's, 1995) menyebutkan bahwa terdapat beberapa nilai penting dalam bermain bagi anak, yaitu:

1. Meningkatkan kemampuan problem solving pada anak

2. Menstimulasi perkembangan bahasa dan kemampuan verbal

3. Mengembangkan ketrampilan social

4. Merupakan wadah pengekspresian emosi

Selain itu, dalam Best Play (Iswinarti, 2010) menyebutkan bahwa peran bermain pada anak berdampak pada sejumlah bidang kehidupan anak, yaitu sebagai berikut:

1. Bermain mempunyai peran yang penting dalam belajar. Dalam hal ini, bermain dapat melengkapi kegiatan sekolah anak, yang dapat memberi kesempatan kepada anak untuk memahami, meresapi, dan memberi arti kepada apa yang mereka pelajari dalam seting pendidikan formal. Secara khusus, bermain menjadi penting yaitu membantu anak untuk memperoleh "bukan informasi khusus, tetapi mindset umum dalam pemecahan masalah".

2. Bermain dapat mendukung perkembangan fisik dan kesehatan mental yang baik. Bermain memfasilitasi anak dalam beraktivitas fisik, meliputi kegiatan berolah raga,

3. yang mengungkinkan meningkatnya koordinasi dan keseimbangan tubuh, serta mengembangkan keterampilan dalam pertumbuhan anak. Adapun sumbangan untuk kesehatan mental adalah membantu anak untuk membangun dan mengembangkan resiliensi (daya tahan) terhadap tekanan dalam hidup.

4. Bermain memberi kesempatan untuk menguji anak dalam mengahadapi tantangan dan bahaya.

(Misbach, 2006) dalam penelitiannya menunjukkan bahwa permainan tradisional dapat menstimulasi berbagai aspek perkembangan anak yang dapat meliputi hal-hal sebagai berikut :

1. Aspek motorik dengan melatih daya tahan, daya lentur, sensori motorik, motorik kasar, dan motorik halus.

2. Aspek kognitif dengan mengembangkan imaginasi, kreativitas, problem solving, strategi, kemampuan antisipatif, dan pemahaman kontekstual.

3. Aspek emosi dengan menjadi media katarsis emosional, dapat mengasah empati dan pengendalian diri.

4. Aspek bahasa berupa pemahaman konsep-konsep nilai.

5. Aspek sosial dengan mengkondisikan anak agar dapat menjalin relasi, bekerjasama, melatih kematangan sosial dengan teman sebaya dan meletakkan pondasi untuk melatih keterampilan sosialisasi dengan berlatih peran dengan orang yang lebih dewasa dan masyarakat secara umum.

6. Aspek spiritual, permainan tradisonal dapat membawa anak untuk menyadari keterhubungan dengan sesuatu yang bersifat Agung (transcendental). 
7. Aspek ekologis dengan memfasilitasi anak untuk dapat memahami pemanfaatan elemenelemen alam sekitar secara bijaksana.

8. Aspek nilai-nilai/moral dengan memfasilitasi anak untuk dapat menghayati nilai-nilai moral yang diwariskan dari generasi terdahulu kepada generasi selanjutnya.

Anne menyebutkan bahwa terdapat beberapa pengaru atau manfaat dari melakukan permainan tradisional terhadap perkembangan jiwa anak, yaitu:

1. Menjadi lebih kreatif. Permainan tradisional biasanya dibuat langsung oleh para pemainnya. Mereka menggunakan barang atau benda bahkan tumbuhan yang ada di sekitar para pemain. Hal ini mendorong mereka untuk menjadi lebih kreatif menciptakan alat permainan

2. Bisa digunakan sebagai terapi terhadap anak. Saat bermain anak anak akan melepaskan emosinya. Mereka berteriak, tertawa dan bergerak. Kegiatan semacam ini bisa digunakan sebagai terapi ntuk anak anak yang memerlukan kondisi tersebut.

3. Mengembangkan kecerdasan majemuk anak

4. Mengembangkan kecerdasan natural anak

5. Mengembangkan kecerdasan spasial anak

6. Mengembangkan kecerdasan musical anak

7. Mengembangkan spiritual anak

Indonesia sebagai negara yang kaya akan permainan tradisional memiliki berbagai macam jenis permaian di masing masing daerah, misalnya gobak sodor, petak umpet, angkling atau engklek, dakon atau congklak, egrang, lompat tali, lempar batu atau gatheng, bola bekel, ular naga, layanglayang, cublak-cublak suweng, jamuran, kotak pos, sepak sekong, cendak beralih, gundu or kelereng, bentik, ABC lima dasar, benteng-bentengan, balap karung, rumah rumahan tanah, boi-boinan, gasingan, gatrik, kasti, lenggang rotan, masak-masakan, donal bebek, bakiak atau teklek, polisipolisian, rangku alu, paraga, pletokan, amelia-amelia, kucing dan tikus, ketapel, lari tempurung, mendorong ban, mercon bambu, ngadu muncang, dan lain sebagainya.

\section{Gobak Sodor}

Gobak sodor merupakan salah satu permainan yang membutuhkan keterlibatan banyak orang. Dalam permainan tersebut, pemain dibagi menjadi dua tim dengan anggota masing-masing minimal tiga orang. Satu tim bertugas untuk menjaga daerahnya, sedangkan tim yang lainnya berusaha untuk menembus daerah yang dijaga oleh tim lawan. Tim yang mendapat tugas untuk menyerang harus bisa melewati daerah yang berupa kotak-kotak yang telah dibuat dengan tidak boleh tersentuh oleh anggota tim yang berjaga. Apabila tim penyerang tersentuh, permainan berakhir dan kedua tim bertukar posisi. Yang sebelumnya menjadi tim penyerang berganti menjadi tim jaga. Poin yang didapat dihitung dari jumlah pemain yang bisa menembus daerah jaga dan kembali lagi ke daerah awal. 
Permainan gobak sodor ini dapat melatih ketangkasan, kewaspadaan, kecepatan, serta kerja sama. Maka dari itu, jika anak-anak sudah sering memainkan permainan ini, hal itu adalah hal yang positif. Persiapan untuk bermain pun tidak terlalu rumit, hanya sebuah tanah kosong ukuran $20 \times 10$ meter dan minimal 6 orang permainan sudah bisa dilakukan.

Selain melatih ketangkasan, kecepatan, juga kewaspadaan yang merupakan latihan untuk memperkuat fisik pada anak, permainan Gobak Sodor secara tidak langsung menanamkan nilai nilai moral pada anak, misalnya sportivitas, kejujuran, menghormati orang lain, teamwork, tanggung jawab, menghargai perbedaan orang lain karena permainan ini merupakan permainan tim.

\section{Petak Umpet}

Petak umpet merupakan permainan yang sangat mudah dilakukan. Prinsip permainan ini adalah menemukan orang yang bersembunyi. Orang yang bersembunyi yang pertama kali ditemukan adalah orang yang akan bergantian menjadi si pencari atau sering disebut dengan penjaga pos. Apabila penjaga tidak dapat menemukan semua pemain dan menyatakan menyerah, dia dinyatakan kalah. Permainan ini dapat dilakukan minimal oleh dua orang. Akan tetapi, permainan akan menjadi lebih seru apabila semakin banyak pemain yang terlibat karena dengan banyaknya pemain, tempat untuk bersembunyi pun menjadi terbatas dan kemungkinan ditemukan menjadi semakin besar. Maka dari itu, permainan ini mengasah kreativitas dan kepekaan pemainnya. Untuk aturan permainan, seorang pemain akan menjadi penjaga dengan dipilih melalui suit atau sesuai kesepakatan. Selanjutnya penjaga menutup matanya selama waktu yang ditentukan, antara 10-100 detik. Dalam rentang waktu tersebut, pemain lain berkesempatan untuk segera mencari tempat persembunyian yang paling aman. Setelah hitungan selesai, siap atau tidak si penjaga akan mencari pemain lain dan orang yang pertama kali ditemukan akan menjadi penjaga.

Permainan Petak Umpet mengajarkan kepada anak anak untuk bersikap jujur, misalnya saat menjaga pos maka ia harus jujur untuk tidak membuka mata saat teman temannya atau pemain lainnya sedang berlari untu bersembunyi. Di samping itu, sportivitas juga secara tidak langsung ditanamkan di permainan ini. Misalnya ketika si penjaga pos dapat menemukan tempat persembunyiannya, maka ia harus bersedia untuk menjaga pos.

\section{Engklek}

Permainan Engklek atau Angkling merupakan permainan yang dilakukan dengan cara berjalan dengan satu kaki pada petak-petak berbentuk kotak yang digambar di atas tanah. Ada berbagai jenis petak permainan dalam Angkling atau Engklek, yakni bentuk gunung, kincir, huruf L, dan lain-lain. Aturan bermain dari Angkling atau Engklek adalah pemain melempar koin atau serpihan genting pada kotak-kotak yang telah digambar di tanah secara berurutan, dari petak yang paling dekat dengan pelempar. Pada kotak yang ditandai koin atau serpihan genting, pemain tidak boleh menginjaknya dan harus melewati petak tersebut. Saat kembali ke garis awal, pemain tersebut harus mengambil kembali serpihan genting tersebut dan melanjutkan melempar ke kotak 
berikutnya. Permainan ini dapat dilakukan dengan minimal jumlah pemain dua orang. Selain melatih ketangkasan, permainan ini juga melatih keseimbangan dan konsentrasi.

Pada paragraph sebelumnya disebutkan bahwa permainan engklek dapat melatih ketangkasan, keseimbangan dan konsentrasi. Di samping itu, permainan ini juga mengajarkan untuk menghargai perbedaan, kesetaraan gender karena dapat dimainkan oleh anak laki laki dan perempuan, sportif, juga kejujuran. Dalam permainan ini, si pemain tidak diperkenankan untuk menyentuh garis pembatas pada saat bermain. Jika ia menyentuh garis tersebut maka ia secara jujur mengakui dan harus berhenti bermain.

\section{Dakon}

Dakon atau congklak merupakan permainan tradisional yang popular di Indonesia. Bahkan ada permainan congklak yang bisa dimainkan di smartphone, pada aplikasi Hago sebagai contoh. Permainan dakon atau congklak ini sebenarnya bukan asli dari Indonesia. Dakon diyakini oleh beberapa ahli sejarah sebagai sebuah permainan yang dibawa pedagang asal Arab yang datang ke Indonesia. Aturan main permainan dakon tidak terlalu susah. Area permainan dakon berupa tempat lonjong yang terbuat dari plastik, kayu, atau tanah yang dibuat lubang dengan jumlah 12 lubang. Lubang-lubang tersebut diisi dengan kecik (biji sawo) atau kerikil. Pemain akan mengambil kecik dari satu lubang dan membagikannya satu persatu selain lubang 'tabungan' milik lawan secara berurutan. Kecik terakhir yang jatuh di lubang yang ada isinya harus dipungut lagi dan di sebar lagi. Permainan ini hanya dapat dilakukan oleh dua pemain saja. Biasanya, pemain yang suka bermain dakon adalah wanita, meskipun tidak ada pula anak laki laki yang bermain permainan ini juga. Banyak manfaat yang bisa didapatkan dari permainan ini, yakni melatih kecerdasan karena untuk memenangkan permainan ini dibutuhkan strategi yang tepat.

Permainan dakon tidak hanya melatih strategi seorang anak dalam bermain, namun juga mengajarkan nilai moral untuk memiliki sifat sportif dan jujur. Di samping itu, tidak ada pembeda ketika permainan ini dimainkan oleh laki laki ataupun perempuan, meskipun ada beberapa yang menyebutkan bahwa permainan ini lebih sering dimainkan oleh perempuan. Dengan ini, anak akan belajar saling menghargai antara laki laki dan perempuan.

\section{Lompat Tali}

Permainan lompat tali adalah permainan yang melatih ketangkasan, konsentrasi, dan kelincahan. Permainan ini minimal dilakukan oleh tiga orang, dua orang sebagai pemegang tali dan satu orang sebagai pelompat tali. Tali yang dipakai terbuat dari karet gelang yang disambungsambungkan dengan simpul tertentu. Namun, ada juga yang langsung menggunakan tali dalam permainan ini. Aturan permainan dari permainan ini adalah dua orang pemegang tali mengatur tinggi talinya setinggi lutut, kemudian pelompat harus berhasil melompati tali tersebut. Jika berhasil, maka tinggi tali dinaikkan menjadi seperut, sedada, telinga, kepala, dan terakhir setinggi tangan diangkat di 
atas kepala (istilahnya 'merdeka'). Jika pemain gagal dalam melompati tali tersebut, dia harus bergantian menjadi pemegang tali.

Pada dasarnya permainan ini merupakan permainan individu, meskipun dimainkan paling tidak 3 anak. Hal ini karena pemain yang melompat memiliki tugas individu untuk dapat melewati tali dengan ketinggian tertentu. Permainan lompat tali dapat dilakukan oleh siapapun baik laki laki maupun perempuan. Dengan demikian, permainan ini bagaimana saling menghormati dan menghargai, bersikap sportif dan jujur.

\section{Bola Bekel}

Hampir mirip dengan gatheng, permainan bola bekel juga memiliki aturan harus mengambil beberapa kecik ketika melempar bola. Yang membedakan antara keduanya adalah dalam bola bekel, bola tidak harus langsung ditangkap, namun dibiarkan memantul satu kali terlebih dahulu sebelum ditangkap. Perlengkapan untuk permainan ini adalah satu bola karet dan sedikitnya empat kecik yang biasanya terbuat dari plastik atau logam. Cara bermainnya, pemain memantulkan bola karet dan mengambil kecik satu-satu, lalu dua-dua, dan seterusnya. Setelah itu, kecik di bolak-balik dengan posisi tertentu. Hal ini harus dilakukan dalam maksimal satu pantulan bola karet. Jika pemain gagal mengambil kecik atau bola memantul lebih dari satu kali, dia dinyatakan gagal dan diteruskan pemain lainnya.

Permainan bola bekel ini cukup popular di kalangan anak anak, dimana permainan ini paling tidak dimainkan oleh dua anak yang mengadu ketangkasan mereka dalam memainkan bola bekel dan kecik. Kejujuran dan sportifivitas diajarkan sekali dalam permainan ini, karena ada banyak kemungkinan seseorang bermain curang agar ia mencapai goal lebih dahulu daripada lawannya jika lawan tidak mengetahui bahwa kecik kecik tersebut terjatuh atau tersenggol. Hal ini, karena kadang si lawan tidak melihat sekilas saat lawannya bermain. Ketelitian juga diajarkan dalam permainan ini.

\section{Simpulan}

Dari diskusi di atas, dapat disimpulkan bahwa terdapat beberapa cara yang dapat dilakukan untuk menanamkan Pendidikan karakter pada anak, dan menggunakan permaian tradisional merupakan salah satu pilihan yang dapat digunakan. Terdapat beberapa hal yang dapat digarisbawahi dan menjadi nilai tambah mengapa permainan tradisional perlu digunakan, 1) bahwa permainan tardisional merupakan warisan leluhur bangsa Indonesia; 2) bahwa permainan tradisional mengandung nilai moral; 3) bahwa dengan tetap memainkan permainan tradisional berarti ikut serta dalam melestarikan budaya bangsa. Di samping itu, permainan tradisional juga tidak hanya mengajarkan tentang nilai moral, namun juga dapat mengembangkan aspek lain dalam diri anak, misalnya kognitif dan psikomotorik. 
ZAHRA: Research And Tought Elmentary School Of Islam Journal Vol. ( 1) (2), (Agustus)(2020), (Halaman)(1-14)|

Daftar Pustaka

Andriani, Tuti. (2012). Permainan Tradisional dalam Membentuk Karakter Anak Usia Dini. Jurnal Sosial Budaya. 9(1), 121-136.

Dharmamulya, sukirman dkk. (2005). Permainan Tradisional. Purwangan: KEPEL PRESS

Hidayati, Niswatin Nurul (2019). One Package Learning in Improving Language Skill and Implanting Character Education on Children. EDUKASI: Jurnal Pendidikan Islam.7(2). 53-72. DOI: https://doi.org/10.5281/edukasi.v7i2.390

Hidayati, Niswatin Nurul (2019). Telling About Islamic Heroes And Female Leaders: Ways of Implanting Self-Concept, Moral, And Religious Value on Children. Auladuna : Jurnal Prodi Pendidikan Guru Madrasah Ibtidaiyah, 1(2), 1-14. DOI: https://doi.org/10.36835/au.v1i2.227

Hidayati, Niswatin Nurul (2020). Language and Brain: Maximizing Children's Brain in Learning Foreign Language Through Storytelling, Songs, and Flashcards. IBRIEZ: Jurnal Kependidikan Dasar Islam Berbasis Sains. 5(1). 57-72.

Hidayati, Niswatin Nurul. (2020). Indonesian Traditional Games: A Way to Implant Character Education on Children and Preserve Indonesian Local Wisdom. ISTAWA: Jurnal Pendidikan Islam (IJPI). 5(1), 81-101. DOI: 10.24269/ijpi.v5i1.2475

Ikhsanudin, Arief. (2018). Ada 504 Kasus Anak Jadi Pelaku Pidana, KPAI Soroti Pengawasan Ortu. Retrieved from https://news.detik.com/berita/d-4128703/ada-504-kasus-anak-jadi-pelakupidana-kpai-soroti-pengawasan-ortu

Iswinarti. (2010). Nilai Nilai Terapiutik Permainan Tradisional Engklek untuk Anak Usia Sekolah Dasar. Naskah Publikasi.

Koran Sindo. (2019). Tindak Kriminalitas Anak Sangat Memprihatinkan. Retrieved from https://nasional.sindonews.com/read/1386542/13/tindak-kriminalitas-anak-sangatmemprihatinkan-1552524624

Latif, Muktar., dkk. (2014) Orientasi Baru Pendidiikan Anak Usia Dini. Jakarta: Kencana.

Misbach, Ifa H. (2006). Peran Permainan Tradisional Yang Bemuatan Edukatif Dalam Menyumbang Karakter Dan Identitas Bangsa. Research Report. Bandung: Universitas Pendidikan Indonesia

Rogers, C.S., JK. Sawyers. (1995). Play in the Lives of Children: American Series in Mathematical and Management Sciences. Washington DC: Natl Assn For the Education.

Tesalonika, Clara., Munawar, Muniroh. (2016). Analisis Nilai Karakter Dalam Permainan Tradisional Kucing Tikus. PAUDIA Jurnal Penelitian dalam Bidang Pendidikan Anak Usia Dini. 5(2), 33-49. 